\title{
Normas para Publicação
}

A revista Análise Econômica é um periódico de publicação semestral na área de Economia. $\mathrm{O}$ autor que deseje publicar seu artigo deve submetê-lo à apreciação crítica e à revisão, conforme as normas da revista.

1. Aceitam-se para publicação trabalhos originais. Eventualmente, serão aceitos artigos já publicados em outro idioma, que, pela sua relevância, possam mere-cer maior divulgação em língua portuguesa. Quando a tradução não for revista pelo autor, será colocada a menção "tradução não revista pelo autor". Aceitam-se, também, notas e comentários sucintos de artigos já publicados, bem como resenhas de livros e teses. A revista Análise Econômica aceita trabalhos em português, inglês e espanhol.

2. Os textos submetidos são, primeiramente, examinados pelos Editores Responsáveis, que avaliam se o texto tem relação com o foco da Revista e se segue as normas para publicação. Nessa fase, o artigo poderá ser recusado.

3. Após exame prévio dos Editores, o trabalho é encaminhado a, pelo menos, dois avaliadores. Nessa etapa, a Revista utiliza o sistema blind review, ou seja, os autores não são identificados em nenhuma fase da avaliação. Por isso, antes de submeter o arquivo, exclua o(s) nome(s) do(s) autor(es) do trabalho submetido. A decisão dos avaliadores é registrada em pareceres, que poderão ser enviados aos autores, mantendo-se em sigilo os nomes desses avaliadores.

4. O texto deve ser digitado em tamanho de papel A4, formatado em espaço simples, corpo 12, em Word, limitando-se a 20 laudas, incluindo notas de rodapé, referências e anexos.

5. Os artigos devem apresentar, em português e em inglês: título; resumo (Abstract), com cerca de 10 linhas; três palavras-chave (Keywords) e Classificação JEL.

6. A apresentação dos trabalhos segue as normas da ABNT. As citações bibli-ográficas devem ser indicadas no próprio texto, contendo entre parênteses o sobrenome do autor, ano da publicação e, se for o caso, o número da página citada. Por exemplo: "Conforme Keynes (1936, p. 39), [...]" ou "(KEYNES, 1936, p. 39)". As notas de rodapé devem ser destinadas exclusivamente a observações adicionais ao texto.

7. As referências completas deverão ser reunidas no fim do texto, em ordem alfabética, e elaboradas segundo a NBR 6023/2002. Exemplo:

SAMUELSON, P. A. Fundamentos da análise econômica. São Paulo: Abril Cultural, 1983. 380p. (Coleção Os Economistas). 
8. As fórmulas matemáticas e as notas de rodapé devem ser numeradas sequencialmente.

9. As ilustrações - tabelas, quadros, gráficos - devem ser numeradas e trazer legendas. Não usar cores além de preto e branco. Sempre indicar a fonte das ilustrações. Caso sejam elaboradas pelo autor, escrever: "Fonte: Elaborada(o) pelo(s) autor(es)".

10. É de responsabilidade do(s) autor(es) providenciar a Revisão Gramatical e Textual do seu trabalho antes de submetê-lo à avaliação.

11. As submissões devem ser feitas on-line. Para iniciar o processo de submissão de artigos basta se cadastrar no site da revista (www.ufrgs.br/rae), clicando em CADASTRO. Nesse cadastro, marque a opção "Autor: Pode submeter à revista" (última opção do formulário). Ao finalizar o cadastro, acesse o site com seu login e senha, e clique em AUTOR. A seguir, inicie a submissão do artigo seguindo os cinco passos indicados pelo sistema. Por este site, é possível acompanhar o progresso do seu artigo dentro do processo editorial.

12. As colaborações não serão remuneradas. Cada autor receberá três exemplares do número em que seu trabalho for publicado, e, caso possua coautor(es), cada um receberá dois exemplares. 